\title{
Evaluating governmental tourism websites in Egypt using Search Engine Optimization tools
}

\author{
Raghda Badr* \\ Hanan Maher \\ Faculty of Tourism and Hotel- Fayoum University
}

\begin{abstract}
Due to the increasing need of organizations to improve their online presence, search engine optimization tools (SEO) have emerged to monitor page hit ratio and hit frequency by users, particularly for governmental tourism organizations which are a target source of information for tourists. Therefore, nine Egyptian governmental tourism websites were chosen for a comparative analysis through SEO tools such as Traffic Estimate, Google trends, Alexa, Similarweb, SEMrush, SEO analyzer, and MOZ (open site explorer). For each SEO tool check, a rank is given, then the average of ranks is calculated to rank the selected websites. Findings revealed that websites face a lot of issues which have a negative impact on its efficiency. Meanwhile, Egyptian Tourism Board website has the highest rank and Ministry of Tourism and Antiquities website is in the second rank.
\end{abstract}

Keywords: Search Engine, Search Engine optimization, SEO Tools, Website Evaluation, Tourism, Egypt.

\section{Introduction}

Internet marketing has become an essential issue for the competition between businesses. Recently, search engine optimization techniques became one of the most leading techniques to improve website ranking. By using efficient keywords, higher ranking website can be secured. In addition, site traffic and popularity increases (Chen et al., 2011).

As the internet was converted with the search engines development in the mid-1990s, those tools gave access to many resources on the web and displayed pertinent links for a user's search. Their fundamental function is explanations and makes contents of websites, which index and rank other websites according to their keywords and make it easier and faster to reach obtained search results. Accordingly, those search engines return millions of documents for each user query with an entered keyword, but the user only looks at a selected few (Gregurec and Grd, 2012).

Search Engine Marketing (SEM) is the most important digital marketing channel for user queries. As all of customers turn to a search engine when they are seeking for a new service, product, some entertainment, or information (Chaffey et al., 2013). Accordingly, the success key to successful SEM is achieving keywords which are relevant to what search engines strive for (Chaffey et al., 2009). Hence, SEM is important to target internet users during their search. It can create a playing field level where small companies can be listed alongside well-known brands to increase their awareness and drive response (Chaffey et al., 2013).Eventually, The main aspect of SEM is search engine optimization, it is the process of trying to rank highly a given webpage or domain for specific keywords (Evans, 2007).

Subsequently, search engine optimization plays an important role in promoting tourism websites at the international level (Vyas, 2019). SEO also helps the webmaster to get top ranking position in the search result list, attracts more online visitors and improves the marketing ability of the website .Furthermore, search engine optimizer helps in establishing a website which can be found easily to search engine crawler with pertinent keywords (Swati et al., 2013).

* Corresponding Author, Raghda Badr, Faculty of Tourism and Hotels, Fayoum University, rmb00@fayoum.edu.eg 
On the other hand, it enhances the traffic of website and improves the website sales ability (Rehman and Khan, 2013). It is also used for brand positioning (Dou et al., 2010), with a good page ranking or good ranking in Google or any other search engines (Chen et al., 2011).

Accordingly, the main objective of SEO techniques is to make a website more preferable in the revealed search result and attract more visitors for higher rank (Rehman and Khan, 2013). Therefore, the main purpose of this paper is to use the SEO tools to compare the Egyptian governmental tourism websites by evaluating their current situation. In addition, it can help the decision-makers to improve the website efficiency to reach its aim.

\section{Literature Review}

\section{Search Engine}

A lot of search engines consisted of services. Services are contrived to process that the user queries run quickly. Generally, every service is devoted to a single operation in the query process (Marin et al., 2019). Hence, search engines are a way with a low cost to get accessibility to the web data (Sánchez et al., 2018).

In the dawn of the internet era, there were a lot of competing search engines like Google, Yahoo, Wiki, etc. But Google modified the platform of the search engine market. It was founded in 1988. Recently, it has approximately $70 \%$ of the search globally (Ji et al., 2016).

Therefore, the most important thing of a search engine is how users access information in a rank algorithm (Lepp et al., 2019). Where all search engines have competition with each other's in the terms of search quality ( $\mathrm{Ji}$ et al., 2016), the search engine result presentation affects the credibility judgment of the user in addition shaping of information (Leppet al., 2019).

Accordingly, users have their own space to choose any appropriate search engine for them (Ji et al., 2016). However, the search engine cannot control the posting contents excluding its indexing for the keywords and the acts of the users who are using search engines (Yew, 2019).

In addition, the provider portfolio is affected by that information whatever for his current or future services or products (Sirdeshmukh et al., 2018).

\section{Search Engine Optimization}

Due to the increasing number of websites and their competition, the need to SEO emerged which correlates with page hit ratio and hits frequency (Egri and Bayrak, 2014).The SEO utilizes search principals to show the highest rank for webpages to make it more accessible (Rehman and Khan, 2013).

Kaur and Kaur, (2017) mentioned that SEO is used to optimize the website code, contribution of website, and website content with the awareness of method followed by SEO to catch webpage and index. Hence, it is a procedure to get higher rank in the search engine results page (Hui et al., 2012). Accordingly, it is the set of processes used to improve traffic quality and volume and work with algorithm method (Multazam and Purnama, 2015; Swati et al., 2013).

Chen et al., (2011) identified SEO in terms of the marketing as it is using data observation and marketing research to identify the most suitable keyword for the site, which is consistent with a view of SEO copyrighting, as most of the used techniques to promote sites in search engines, deal with texts (Ankalkoti, 2017), thus it improves the organization position and its products through choosing keywords to be shown in high rank throughout identifying factors in a webpage that would affect search engine accessibility to it and fine-tuning the many aspects of a website. Hence, it can achieve the highest possible visibility when a search engine responds to a matching query (Gregurec and Grd, 2012) 


\section{On site optimization}

On page optimization contains techniques which are used by the webmaster (Matosevic, 2014) to make its website appear on the first rank when the user inquires (Kaur and Kaur, 2017). Hence, it relies on the webmaster skills and knowledge (Matosevic, 2014). There are a lot of features which must be included during the website design such as appropriate content, titles, keywords, and extra links (Ankalkoti, 2017; Swati et al., 2013).

On page optimization has a lot of aspects which must be included such as: (Rehman and Khan, 2013; Gregurec and Grd, 2012; Al-Badi, 2011; Kaur and Kaur, 2017; Ankalkoti, 2017; Swati et al., 2013; Yalcin and Kose, 2010):

Meta description: Meta description is important on the SEO especially in the marketing strategy as its aim is to declare the website content and is used by the search engines to give a website preview. It must be within 155 characters only.

Meta tags: Meta tags are invisible for the website user but it is an important element for the search engine crawling. It depends mainly on the webmaster view whether to provide it or not and can be replaced by the title tag as it is used by few crawlers. It exists in HTML at the page head.

Title tag: Title tag is the most important factor in the website ranking and page results. It includes the user required keywords and designates the webpage content. It appears in three things browsers, search result pages, and external websites. Hence, it must not exceed 70 characters.

Heading tag: It is important as search engine use it to identify keywords and make the searching process faster. It has six nodes and ignoring it may affect SEO efficiency

Meta robots: It prevents some webpages or some attributes from appearing for many reasons such as making some information private, duplicate content, and controlling bandwidth usage.

Picture tag: Images and pictures which are used in the website content should be correlated to the content. In addition, using original ones is positively affecting the site selection and ranking.

Sitemap: It increases the website visibility in the search engine in addition to easier navigation. It is also essential to notify the search engine about any updates on the site.

Keyword in URL: The website will be found more easily by search engine crawlers if there are efficient keywords included in URL. Also, short length of URL is required in search engine optimization.

Using "index, follow" with the robots' label: Each page must have index and follow definitions. These definitions enable search engine to index the related page and watch the links included in this page.

\section{Off-site optimization}

It is the activities taken outside the original website to affect its rank within search results such as the directory submission, search engine submission of website, link building and link exchange (Kaur and Kaur, 2017; Ankalkoti, 2017).

The following aspects can be adopted for off-site optimization (Matošević, 2014, 333; Kaur and Kaur, 2017; Ankalkoti, 2017):

Back linking: it links a webpage to any other webpage. Therefore, it gives confidence in case of using good reputed webpages. Back links are attained by guest posts, media publication submission, subscribing websites to directories, or others.

Social Network: placing links of social media activities boost the webpage organic traffic through search engines. In addition, this makes other users added their accounts and eventually visit the website. 
Business email: it allows sending emails to people to get data about website products or services.

\section{Joining online community and discussion boards and joining groups.}

\section{Research gap}

Despite the governmental organizations for tourism have a vital role in the tourism industry development in Egypt, and there are a lot of papers such as Abou-Shouk \& Lim, 2010; Hagag et al., 2014; Hefny, 2015; and Abou-Shouk \& Khalifa, 2017 evaluated Egyptian travel agents website in different areas such as the website features which the visitors use, there isn't any research evaluated governmental tourism organization website in Egypt by searching in Google scholar, Science direct, and Egyptian Knowledge Bank databases.

Moreover, there is no research has exposed to compare and rank Egyptian governmental tourism websites by implementing search engine optimization tools which are approaching in this research (Traffic Estimate, Google trends, Alexa, Similarweb, SEMrush, SEO analyzer, and MOZ (open site explorer) to contribute in assessing their current situation and accordingly improve their performance.

\section{Research method}

The governmental organizations are permanent or semi-permanent ones in the structure of the government and responsible for overseeing and managing specific jobs. In tourism industry, there are many governmental organizations concerned with different tourism affairs and integrate with each other's to promote the tourism industry as shown in the following table.

Table 1: Governmental organizations in Egypt for the Tourism Affairs

\begin{tabular}{|l|c|c|}
\hline \multicolumn{1}{|c|}{ Abbreviation } & Website & Organization \\
\hline Egyptian Travel Agents Association & www.etaa-egypt.org & ETAA \\
\hline Egyptian Tourism Board & www.egypt.travel & ETB \\
\hline Misr Travel Agency & www.misrtravel.net & Misr Travel \\
\hline $\begin{array}{l}\text { Ministry of Tourism and Antiquities for Travel } \\
\text { Agencies and Tour Guide Affairs }\end{array}$ & http://trans.hajj.gov.eg/ & MTA-A \\
\hline Ministry of Tourism and Antiquities & www.antiquities.gov.eg & MTA \\
\hline The Holding Company for Tourism and Hotels & www.hotac-eg.com & HOTAC \\
\hline The Egyptian General Company for Tourism and Hotel & Egoth.com.eg & EGOTH \\
\hline Tourism Development Authority & www.tda.gov.eg & TDA \\
\hline Egyptian Tourism Federation & www.etf.org.eg & ETF \\
\hline Tourism Holding Company & - & - \\
\hline Supreme Council of Tourism & - & - \\
\hline Regional Tourism Development Authority & - & - \\
\hline Tourism and Antiquities Police & - & - \\
\hline All Egyptian govich & \\
\hline
\end{tabular}

All Egyptian governmental websites for tourism affairs were chosen for a comparative analysis. Location for all keywords search was Egypt. All organizations have their own website excluding four organizations that do not have website such as the Supreme Council of Tourism and the Regional Tourism Development Authority. Accordingly, those four organizations are excluded in this study as they do not have websites to be evaluated. The data were collected from the period between June 2019 to August 2019.

Seven SEO tools were used to analyze the selected nine websites: Traffic Estimate, Google trends, Alexa, Similarweb, SEMrush, SEO analyzer, and MOZ (open site explorer).

The study tools were conducted by the authors after taking "Search Engine Optimization" course. The study tools are mentioned in Table 2 in detail. 
International Journal of Heritage, Tourism and Hospitality Vol. (13), No. (2), September, 2019 By: Faculty of Tourism and Hotels, Fayoum University

Table 2: Seven SEO tools description

\begin{tabular}{|c|c|c|c|}
\hline Tools Name & Description & Sub tools & Tools measurement \\
\hline $\begin{array}{c}\text { Traffic } \\
\text { Estimate }\end{array}$ & $\begin{array}{l}\text { Contributes to understanding the } \\
\text { searcher's mind. Accordingly, } \\
\text { knowing the keywords which the } \\
\text { searchers would use during } \\
\text { searching for a product, service, } \\
\text { or tourist destination. }\end{array}$ & & \\
\hline \multirow[t]{3}{*}{ Google trend } & \multirow[t]{3}{*}{$\begin{array}{l}\text { Helps to gauge engine users } \\
\text { search behaviors and gain key } \\
\text { insights over a given period. It } \\
\text { provides keywords related data } \\
\text { including search volume index. }\end{array}$} & $\begin{array}{l}\text { Interest over } \\
\text { time }\end{array}$ & $\begin{array}{l}\text { Its value ranges from } 0 \text { to } 100 \text {, } \\
\text { where } 0 \text { means that a sufficient } \\
\text { amount of data was not } \\
\text { available for the selected term } \\
\text { unlike the } 100 \text { value which } \\
\text { means that it is the peak } \\
\text { popularity of the term and value } \\
\text { of the } 50 \text { means that the term is } \\
\text { half as popular. }\end{array}$ \\
\hline & & $\begin{array}{l}\text { Interest by } \\
\text { region }\end{array}$ & $\begin{array}{l}\text { Shows areas where the keyword } \\
\text { phrase is popular. }\end{array}$ \\
\hline & & Related Queries & $\begin{array}{l}\text { Gets the popular terms that } \\
\text { often accompany or follow any } \\
\text { selected search term }\end{array}$ \\
\hline \multirow[t]{3}{*}{ Alexa } & \multirow{3}{*}{$\begin{array}{l}\text { Helps to analyse websites by } \\
\text { SEO tools. It began in } 1996 \text { in } \\
\text { California and was acquired by } \\
\text { Amazon Inc. in } 1999 \text { (Prathapan, } \\
\text { 2018). It depends mainly on data } \\
\text { from more than } 2500 \text { traffic } \\
\text { control servers all over the world } \\
\text { and million internet Alexa users' } \\
\text { data and advertising revenue } \\
\text { (Carretero, 2016). Accordingly, } \\
\text { it categories the websites in } \\
\text { accordance with websites traffic } \\
\text { position }\end{array}$} & Global rank & $\begin{array}{l}\text { Measures the website popularity } \\
\text { all over the world } .1 \text { is being the } \\
\text { most popular }\end{array}$ \\
\hline & & Rank in Egypt & $\begin{array}{l}\text { Measures the website popularity } \\
\text { in Egypt. Rank of } 1 \text { is being the } \\
\text { most popular. }\end{array}$ \\
\hline & & $\begin{array}{l}\text { Website visitors } \\
\text { (Egypt)\% }\end{array}$ & $\begin{array}{l}\text { The percentage of the website } \\
\text { visitors accessed in Egypt. }\end{array}$ \\
\hline \multirow[t]{4}{*}{ Alexa } & & $\begin{array}{l}\text { Bounce } \\
\text { Rate } \%\end{array}$ & $\begin{array}{l}\text { Percentage of visits to the site } \\
\text { that contain a single pageview. } \\
\text { Lower bounce rates do not } \\
\text { translate into higher rankings }\end{array}$ \\
\hline & & $\begin{array}{l}\text { Daily } \\
\text { Page views } \\
\text { Per visitor }\end{array}$ & $\begin{array}{l}\text { Estimated daily unique previews } \\
\text { per visitor on the site. }\end{array}$ \\
\hline & & $\begin{array}{l}\text { Daily time on } \\
\text { Site (mm:ss) }\end{array}$ & $\begin{array}{l}\text { Estimated daily time on site } \\
(\mathrm{mm}: \mathrm{ss}) \text { per visitor on the site }\end{array}$ \\
\hline & & $\begin{array}{l}\text { Search } \\
\text { Traffic } \%\end{array}$ & $\begin{array}{l}\text { Percentage of the visitors who } \\
\text { arrive at a website by clicking } \\
\text { search results leading to that } \\
\text { particular website. }\end{array}$ \\
\hline
\end{tabular}


International Journal of Heritage, Tourism and Hospitality Vol. (13), No. (2), September, 2019 By: Faculty of Tourism and Hotels, Fayoum University

\begin{tabular}{|c|c|c|c|}
\hline Tools Name & Description & Sub tools & Tools measurement \\
\hline & & $\begin{array}{l}\text { Total sites } \\
\text { Linking In }\end{array}$ & $\begin{array}{l}\text { Websites numbers in Alexa } \\
\text { crawl of the web that link to a } \\
\text { website. It improves the } \\
\text { reputation of a website. }\end{array}$ \\
\hline \multirow[t]{2}{*}{ Similarweb } & \multirow{2}{*}{$\begin{array}{l}\text { Provides information on website } \\
\text { traffic volumes, referral sources } \\
\text { as it is the tool that estimates the } \\
\text { total amount of traffic for } \\
\text { different websites. It also allows } \\
\text { to see top referrals which } \\
\text { identify the most important } \\
\text { competitors. }\end{array}$} & $\begin{array}{l}\text { Traffic } \\
\text { Overview }\end{array}$ & $\begin{array}{l}\text { Shows the number of website } \\
\text { visitors, the rate of the highest } \\
\text { country and the method by } \\
\text { which the visitors know the } \\
\text { website. }\end{array}$ \\
\hline & & $\begin{array}{l}\text { Top Referring } \\
\text { Site }\end{array}$ & $\begin{array}{l}\text { Shows a list of the top } 10 \\
\text { inbound and outbound referral } \\
\text { sites. }\end{array}$ \\
\hline \multirow[t]{4}{*}{ SEMrush } & \multirow{4}{*}{$\begin{array}{l}\text { Manages over } 800 \text { million } \\
\text { keywords within over } 130 \\
\text { million domains world widely to } \\
\text { afford SEO competitive research } \\
\text { service of the websites. }\end{array}$} & Organic traffic & $\begin{array}{l}\text { Monitors how the website traffic } \\
\text { and rankings rise over time }\end{array}$ \\
\hline & & Paid traffic & $\begin{array}{l}\text { Monitors the website traffic } \\
\text { which is accessed via } \\
\text { advertisements or other paid } \\
\text { methods to rank rise over time. }\end{array}$ \\
\hline & & SEMrush rank & $\begin{array}{l}\text { Measures the website popularity } \\
\text { all over the world with } \\
\text { SEMrush Rank of } 1 \text { being the } \\
\text { most popular. }\end{array}$ \\
\hline & & Traffic cost & $\begin{array}{l}\text { Determines how much that site's } \\
\text { organic traffic worth. }\end{array}$ \\
\hline SEO analyzer & $\begin{array}{l}\text { Analyses website traffic growth } \\
\text { and page level SEO, } \\
\text { www.nailpatel.com was used. }\end{array}$ & Page Level SEO & Tests on site optimization tools. \\
\hline \multirow[t]{2}{*}{ Moz } & \multirow[t]{2}{*}{$\begin{array}{l}\text { Formed in } 2004 \text { as a referring } \\
\text { firm, and in } 2007 \text { it concentrates } \\
\text { on the development of the own } \\
\text { software for analyzing SEO } \\
\text { indicators. }\end{array}$} & $\begin{array}{l}\text { Domain } \\
\text { Authority }\end{array}$ & $\begin{array}{l}\text { Ranks score predicts how well a } \\
\text { website will rank on search } \\
\text { engine result pages. A Domain } \\
\text { Authority score ranges from one } \\
\text { to one hundred, with higher } \\
\text { scores corresponding to a } \\
\text { greater ability to rank. }\end{array}$ \\
\hline & & Page authority & $\begin{array}{l}\text { Predicts how well a } \\
\text { specific page will rank on } \\
\text { search engine } \\
\text { result pages (SERP). Page } \\
\text { Authority scores range from one } \\
\text { to } 100 \text {, with higher scores } \\
\text { corresponding to a greater } \\
\text { ability to rank }\end{array}$ \\
\hline
\end{tabular}

To complete the comparative study between the nine websites, individual ranks to nine websites are set based on the seven SEO tools for every website. Then the average of every website rank is calculated. Accordingly, every website has its rank as shown in the last column of table 11.

\section{Analysis and results}

By searching for the most used keyword phrases in the tourism sector by Google trend, "Travel to Egypt", "Egypt tours", "Places to visit in Egypt", and "Tourism in Egypt " are the first four 
ones. So, these four keyword phrases were used in the study. While using the keyword phrase "travel to Egypt" none of the Egyptian governmental websites appeared on the top rank. The prevalent sites on the list were selectegyt.com and nogatoursand travel. While as using the keyword phrase "Egypt tours" the same results appeared excluding the top list websites. As memphistours.com, onthegotours.com, affordabletours.com, askaladdin.com, and pilgrimtours.com were appeared on the top list.

Table 3: Google Trends result using four keywords

\begin{tabular}{|c|c|c|c|}
\hline Related Queries & Interest by region & Interest Over Time & keywords \\
\hline Egypt tour & 60 & $\begin{array}{l}\text { Laos, } 60 \\
\text { Armenia ,63 } \\
\text { Vietnam, } 26 \\
\text { Nepal, 25 } \\
\text { United Arab Emirates, } 24\end{array}$ & $\begin{array}{l}\text { Tour to egypt, } 99 \\
\text { Egypt tour packages, } 81 \\
\text { Tour of Egypt, } 63 \\
\text { Egypt package tour, } 54 \\
\text { Egypt Jordan tour, } 53 \\
\text { Egypt tours, } 47\end{array}$ \\
\hline Travel to Egypt & 90 & $\begin{array}{l}\text { Egypt, } 100 \\
\text { United Arab Emirates, } 52 \\
\text { United Kingdom, } 51 \\
\text { Qatar, } 31 \\
\text { Australia, } 30 \\
\text { New Zealand, } 30\end{array}$ & $\begin{array}{l}\text { Safe to travel to egypt,99 } \\
\text { travel to Egypt safe, } 98 \\
\text { Egypt safe to travel,97 } \\
\text { Is Egypt safe to travel to, } 89 \\
\text { Is it safe to travel to Egypt, } 62\end{array}$ \\
\hline $\begin{array}{l}\text { Places to visit in } \\
\text { Egypt }\end{array}$ & 14 & $\begin{array}{l}\text { Egypt, } 100 \\
\text { United Arab Emirates, } 58 \\
\text { United Kingdom, } 11 \\
\text { India, } 10 \\
\text { Canada, } 7 \\
\text { United States, } 6\end{array}$ & $\begin{array}{l}\text { Best places to visit in Egypt, } 100 \\
\text { Places to visit in Cairo Egypt, } 57 \\
\text { Places to visit in Cairo, } 49 \\
\text { Top places to visit in Egypt, } 35\end{array}$ \\
\hline Tourism in Egypt & 3 & $\begin{array}{l}\text { Egypt, } 100 \\
\text { South Africa, } 5 \\
\text { United Kingdom, } 2 \\
\text { India, } 2 \\
\text { Canada, } 2 \\
\text { United States, } 1\end{array}$ & Not enough data \\
\hline
\end{tabular}

Table 3 indicates, by using trends.google.com, the analysis of : 1-internet over time, 2- internet by region and 3-related queries which were conducted by comparing four keywords, Egypt tour, tourism in Egypt, places to visit in Egypt and travel to Egypt, during the past 12 months. Internet over time was found 90, 60, 14, and 3 for travel to Egypt, Egypt tour, places to visit in Egypt, and tourism in Egypt respectively, whihc means that "Travel to Egypt" is the most used one, so the marketing manager can use it to improve the website rank. It was between 20-26 July 2019. There were also many related queries for all keywords phrases expect tourism in Egypt such as Tour to Egypt, Safe to travel to Egypt, Best places to visit in Egypt, etc.

Table 4: Alexa Metrics of government tourism websites

\begin{tabular}{|l|l|l|l|l|l|l|l|l|}
\hline $\begin{array}{l}\text { Governmental } \\
\text { tourism } \\
\text { Organization }\end{array}$ & $\begin{array}{l}\text { Global } \\
\text { Rank }\end{array}$ & $\begin{array}{l}\text { Rank } \\
\text { in } \\
\text { Egypt }\end{array}$ & $\begin{array}{l}\text { Website } \\
\text { Visitors } \\
\text { (Egypt) \% }\end{array}$ & $\begin{array}{l}\text { Bounce } \\
\text { Rate \% }\end{array}$ & $\begin{array}{l}\text { Dail Page } \\
\text { views Per } \\
\text { visitor }\end{array}$ & $\begin{array}{l}\text { Daily time } \\
\text { on Site } \\
\text { (mm:ss) }\end{array}$ & $\begin{array}{l}\text { Search } \\
\text { Traffic } \\
\text { \% }\end{array}$ & $\begin{array}{l}\text { Total sites } \\
\text { Linking In }\end{array}$ \\
\hline TDA & 3438774 & $\mathrm{Na}$ & $\mathrm{Na}$ & - & 2 & $2: 25$ & - & 12 \\
\hline MTA- A & 390969 & 8740 & 82.1 & 49.5 & 2.5 & $1: 50$ & 73.3 & 189 \\
\hline ETB & 236314 & 6367 & 56.4 & 70.2 & 2.5 & $2: 35$ & 67.6 & 896 \\
\hline EGOTH & 2732974 & $\mathrm{Na}$ & $\mathrm{Na}$ & - & 1 & $2: 18$ & - & 11 \\
\hline
\end{tabular}


International Journal of Heritage, Tourism and Hospitality Vol. (13), No. (2), September, 2019 By: Faculty of Tourism and Hotels, Fayoum University

\begin{tabular}{|l|l|l|l|l|l|l|l|l|}
\hline $\begin{array}{l}\text { Governmental } \\
\text { tourism } \\
\text { Organization }\end{array}$ & $\begin{array}{l}\text { Global } \\
\text { Rank }\end{array}$ & $\begin{array}{l}\text { Rank } \\
\text { in } \\
\text { Egypt }\end{array}$ & $\begin{array}{l}\text { Website } \\
\text { Visitors } \\
\text { (Egypt) \% }\end{array}$ & $\begin{array}{l}\text { Bounce } \\
\text { Rate \% }\end{array}$ & $\begin{array}{l}\text { Dail Page } \\
\text { views Per } \\
\text { visitor }\end{array}$ & $\begin{array}{l}\text { Daily time } \\
\text { on Site } \\
\text { (mm:ss) }\end{array}$ & $\begin{array}{l}\text { Search } \\
\text { Traffic } \\
\text { \% }\end{array}$ & $\begin{array}{l}\text { Total sites } \\
\text { Linking In }\end{array}$ \\
\hline Misr Travel & 272968 & 4830 & 90.1 & 33.7 & 11 & $13: 54$ & 32.8 & 65 \\
\hline ETF & 8579774 & $\mathrm{Na}$ & $\mathrm{Na}$ & - & 1 & - & $\mathrm{Na}$ & 69 \\
\hline HOTAC & 2483829 & $\mathrm{Na}$ & $\mathrm{Na}$ & 50 & 2 & $2: 15$ & $\mathrm{Na}$ & 2 \\
\hline MTA & 437611 & 11630 & 80.9 & 61.5 & 1.9 & $1: 54$ & 90 & 67 \\
\hline ETAA & 120872 & 1491 & 95.8 & 28.5 & 5.2 & $8: 29$ & 12.6 & 106 \\
\hline
\end{tabular}

Based on Alexa metrics "table 4", the rank of the nine tourism governmental websites of Egypt was given as shown in table 5. ETAA website has the best rank among other websites globally and in Egypt also. It is also having the highest visitors number with $95.8 \%$ from Egypt. Meanwhile Misr Travel website has the highest time that the visitors spend on it which means it has a good content.

Table 5: Individual ranking of organization according to Alexa metrics factors

\begin{tabular}{|l|l|l|l|l|l|l|l|l|}
\hline Rank & $\begin{array}{l}\text { Global } \\
\text { Rank }\end{array}$ & $\begin{array}{l}\text { Rank in } \\
\text { Egypt }\end{array}$ & $\begin{array}{l}\text { Website } \\
\text { Visitors } \\
\text { (Egypt })\end{array}$ & $\begin{array}{l}\text { Bounce } \\
\text { Rate } \%\end{array}$ & $\begin{array}{l}\text { Dail Page } \\
\text { views Per } \\
\text { visitor }\end{array}$ & $\begin{array}{l}\text { Daily time } \\
\text { on Site } \\
(\mathbf{m m}: \mathbf{s s})\end{array}$ & $\begin{array}{l}\text { Search } \\
\text { Traffic } \\
\boldsymbol{\%}\end{array}$ & $\begin{array}{l}\text { Total sites } \\
\text { Linking In }\end{array}$ \\
\hline 1 & ETAA & ETAA & ETAA & ETAA & $\begin{array}{l}\text { Misr } \\
\text { Travel }\end{array}$ & $\begin{array}{l}\text { Misr } \\
\text { Travel }\end{array}$ & MTA & ETB \\
\hline 2 & ETB & $\begin{array}{l}\text { Misr } \\
\text { Travel }\end{array}$ & $\begin{array}{l}\text { Misr } \\
\text { Travel }\end{array}$ & $\begin{array}{l}\text { Misr } \\
\text { Travel }\end{array}$ & ETAA & ETAA & MTA-A & MTA-A \\
\hline 3 & $\begin{array}{l}\text { Misr } \\
\text { Travel }\end{array}$ & MTA-A & MTA- A & MTA-A & MTA- A & ETB & ETB & ETAA \\
\hline 4 & MTA-A & MTA & HOTAC & HOTAC & ETB & TDA & $\begin{array}{l}\text { Misr } \\
\text { Travel }\end{array}$ & ETF \\
\hline 5 & MTA & ETB & MTA & MTA & TDA & EGOTH & ETAA & MTA \\
\hline 6 & HOTAC & HOTAC & ETB & ETB & HOTAC & HOTAC & TDA & Misr Travel \\
\hline 7 & EGOTH & EGOTH & EGOTH & EGOTH & MTA & MTA & EGOTH & TDA \\
\hline 9 & TDA & TDA & TDA & TDA & EGOTH & MTA-A & HOTAC & EGOTH \\
\hline
\end{tabular}

Hence, there is consistency between global rank and national rank for all websites expect ETB and Misr travel websites.

Table 6: Modal ranks of the websites (Alexa metrics)

\begin{tabular}{|l|l|l|l|l|l|l|l|l|}
\hline $\begin{array}{l}\text { Governmental } \\
\text { tourism } \\
\text { Organization }\end{array}$ & $\begin{array}{l}\text { Global } \\
\text { Rank }\end{array}$ & $\begin{array}{l}\text { Rank } \\
\text { in } \\
\text { Egypt }\end{array}$ & $\begin{array}{l}\text { Website } \\
\text { Visitors } \\
\text { (Egypt) \% }\end{array}$ & $\begin{array}{l}\text { Bounce } \\
\text { Rate \% }\end{array}$ & $\begin{array}{l}\text { Dail Page } \\
\text { views Per } \\
\text { visitor }\end{array}$ & $\begin{array}{l}\text { Daily time } \\
\text { on Site } \\
\text { (mm:ss) }\end{array}$ & $\begin{array}{l}\text { Search } \\
\text { Traffic } \\
\text { \% }\end{array}$ & $\begin{array}{l}\text { Total sites } \\
\text { Linking In }\end{array}$ \\
\hline ETAA & 1 & 1 & 1 & 1 & 2 & 2 & 5 & 3 \\
\hline ETB & 2 & 3 & 5 & 6 & 4 & 3 & 3 & 1 \\
\hline Misr Travel & 3 & 2 & 2 & 2 & 1 & 1 & 4 & 6 \\
\hline MTA- A & 4 & 4 & 3 & 3 & 3 & 8 & 2 & 2 \\
\hline MTA & 5 & 5 & 4 & 5 & 7 & 7 & 3 & 5 \\
\hline HOTAC & 6 & 6 & 6 & 4 & 6 & 6 & 8 & 9 \\
\hline EGOTH & 7 & 7 & 7 & 7 & 8 & 5 & 7 & 8 \\
\hline TDA & 8 & 8 & 8 & 8 & 5 & 4 & 6 & 7 \\
\hline ETF & 9 & 9 & 9 & 9 & 9 & 9 & 9 & 4 \\
\hline
\end{tabular}


As shown in table 6 ETAA website is the only one which ranks the first in four out of eight factors. In the last rank, ETF websites repeat itself in seven factors. Hence, all websites are given ranks for the eight criteria.

Table 7: Traffic overview and referring site according to SimilarWeb

\begin{tabular}{|c|c|c|c|c|}
\hline \multirow{2}{*}{$\begin{array}{c}\text { Governmental } \\
\text { tourism Websites }\end{array}$} & \multicolumn{3}{|c|}{ Traffic Overview } & \multirow[t]{2}{*}{ Top Referring Site } \\
\hline & $\begin{array}{l}\text { Total visits } \\
\left({ }^{\circ} 000\right)\end{array}$ & $\begin{array}{c}\text { Traffic by } \\
\text { country (\%) }\end{array}$ & $\begin{array}{c}\text { Traffic Source } \\
(\%)\end{array}$ & \\
\hline $\begin{array}{l}\text { www.egypt.travel } \\
\text { ETB }\end{array}$ & 48 & $\begin{array}{l}\text { 24.5 Egypt } \\
12.09 \text { United } \\
\text { states }\end{array}$ & $\begin{array}{l}\text { Direct } 20.78 \\
\text { Referrals } 2.86 \\
\text { Search } 68.59 \\
\text { Social } 1.83 \\
\text { Mail 0 } \\
\text { Display } 5.94\end{array}$ & $\begin{array}{l}\text { http://aegyptisches- } \\
\text { fremdenverkehrsamt.de/ }\end{array}$ \\
\hline
\end{tabular}

Meanwhile studying traffic overview and referring site according to similar web. The only website which appeared in similar web metrics is Egypt travel. The biggest traffic was from Egypt the United States. Meanwhile, the highest percentage which visited the websites was via the search engines.

Table 8: SEMRUSH domain overview

\begin{tabular}{|c|c|c|c|c|}
\hline $\begin{array}{c}\text { Governmental } \\
\text { tourism organizations }\end{array}$ & $\begin{array}{c}\text { Organic } \\
\text { Search traffic }\end{array}$ & $\begin{array}{c}\text { Paid Search } \\
\text { traffic (\%) }\end{array}$ & $\begin{array}{c}\text { SEMrush } \\
\text { Rank }\end{array}$ & $\begin{array}{c}\text { Traffic Cost } \\
\text { ('000\$) }\end{array}$ \\
\hline TDA & 264 & 0 & 23500 & 3 \\
\hline MTA-A & 13700 & 0 & 2200 & 301 \\
\hline ETB & 0 & 0 & 1700 & 5 \\
\hline EGOTH & 122 & 0 & 35000 & 27 \\
\hline Misr Travel & 48000 & 0 & 53900 & 9 \\
\hline ETF & 0 & 0 & 255000 & 0 \\
\hline HOTAC & 156 & 0 & 31000 & 12 \\
\hline MTA & 298 & 0 & 200000 & 161 \\
\hline ETAA & 83 & 0 & 400000 & 0 \\
\hline
\end{tabular}

By using SEMrush to get domain overview as shown in table 8. Misr travel website tops the list with 48000 in organic search traffic, meanwhile all the nine websites have $0 \%$ paid search traffic. ETB website ranks the highest according to the Semruah rank, unlike ETAA website which is in the last rank. Meanwhile, the highest traffic cost was 5000\$ for MTA-A website.

Table 9: Page Level SEO using SEO Analyzer

\begin{tabular}{|l|l|}
\hline \multicolumn{1}{|c|}{ Governmental tourism organizations } & \multicolumn{1}{c|}{ Page Level SEO } \\
\hline TDA & $\begin{array}{l}\text { with no sitemap.xml to optimize interaction with bots } \\
\text { without a valid SSL certificate }\end{array}$ \\
\hline MTA-A & $\begin{array}{l}\text { with no sitemap.xml to optimize interaction with bots } \\
\text { without a valid SSL certificate } \\
17 \text { pages have a low word count }\end{array}$ \\
\hline ETB & $\begin{array}{l}\text { with no sitemap.xml to optimize interaction with bots } \\
\text { without a valid SSL certificate } \\
17 \text { pages have a low word count }\end{array}$ \\
\hline EGOTH & $\begin{array}{l}\text { with no sitemap.xml to optimize interaction with bots } \\
\text { without a valid SSL certificate } \\
\text { 49 pages have a low word count }\end{array}$ \\
\hline \multirow{2}{*}{ Misr Travel } & $\begin{array}{l}\text { with no sitemap.xml to optimize interaction with bots } \\
\text { without a valid SSL certificate }\end{array}$ \\
\hline
\end{tabular}


International Journal of Heritage, Tourism and Hospitality Vol. (13), No. (2), September, 2019 By: Faculty of Tourism and Hotels, Fayoum University

\begin{tabular}{|l|l|}
\hline \multicolumn{1}{|c|}{ Governmental tourism organizations } & \multicolumn{1}{c|}{ Page Level SEO } \\
\hline ETF & $\begin{array}{l}\text { with no sitemap.xml to optimize interaction with bots } \\
\text { without a valid SSL certificate }\end{array}$ \\
\hline HOTAC & $\begin{array}{l}\text { with no sitemap.xml to optimize interaction with bots } \\
\text { without a valid SSL certificate }\end{array}$ \\
\hline MTA & $\begin{array}{l}\text { With no sitemap.xml to optimize interaction with bots } \\
\text { without a valid SSL certificate } \\
2 \text { pages with no meta description }\end{array}$ \\
\hline ETAA & with no sitemap.xml to optimize interaction with bots \\
& 137 pages have a low word count \\
& 146 pages with duplicate <title> tags \\
\hline
\end{tabular}

By using www.neilpatel.com as shown in table 8 to run the page level SEO analysis. All nine websites have "no sitemap .xml" error. They are also without valid SSL certificate expect ETAA website. Hence, all websites have several errors which affect their performance.

Table 10: Domain authority and page authority

\begin{tabular}{|c|c|c|}
\hline Governmental tourism organizations & DomainAuthority & Page authority \\
\hline TDA & $17 / 100$ & $24 / 100$ \\
\hline MTA-A & - & - \\
\hline ETB & $67 / 100$ & $57 / 100$ \\
\hline EGOTH & $23 / 100$ & $26 / 100$ \\
\hline Misr Travel & $25 / 100$ & $32 / 100$ \\
\hline ETF & - & - \\
\hline HOTAC & $16 / 100$ & $29 / 100$ \\
\hline MTA & $55 / 100$ & $40 / 100$ \\
\hline ETAA & $26 / 100$ & $46 / 100$ \\
\hline
\end{tabular}

As shown in table 10 the Egypt travel website scored the highest in both domain authority and page authority by using MOZ (open site explorer). Meanwhile there is no data available for MAT-A and ETF websites.

Table 11: Rank Comparison using all metrics

\begin{tabular}{|c|c|c|c|c|c|c|c|c|c|}
\hline 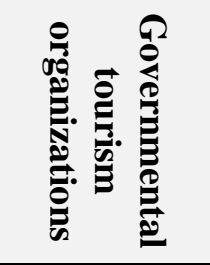 & 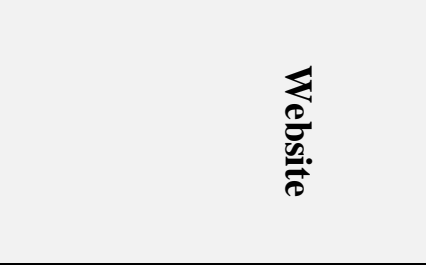 & $\frac{d}{0}$ & 俤 & 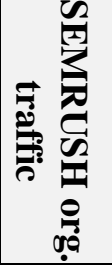 & 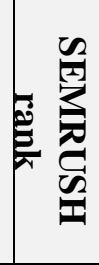 & 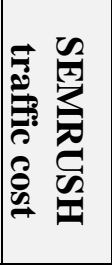 & $\frac{2}{3}$ & 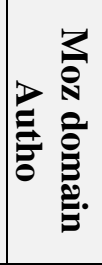 & 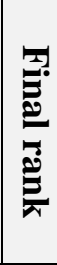 \\
\hline TDA & www.tda.gov.eg & 7 & - & 4 & 3 & 7 & 6 & 7 & 8 \\
\hline MTA-A & http://trans.hajj.gov.eg/ & 4 & - & 2 & 2 & 1 & 8 & 8 & 3 \\
\hline ETB & www.egypt.travel & 3 & 1 & 1 & 1 & 6 & 1 & 1 & 1 \\
\hline EGOTH & Egoth.com.eg & 8 & - & 6 & 5 & 3 & 5 & 6 & 7 \\
\hline Misr Travel & www.misrtravel.net & 2 & - & 8 & 6 & 5 & 4 & 4 & 4 \\
\hline ETF & www.etf.org.eg & 9 & - & 9 & 7 & 8 & 8 & 8 & 9 \\
\hline HOTAC & www.hotac-eg.com & 6 & - & 5 & 4 & 4 & 7 & 5 & 6 \\
\hline MTA & www.antiquities.gov.eg & 5 & - & 3 & 8 & 2 & 2 & 3 & 2 \\
\hline
\end{tabular}




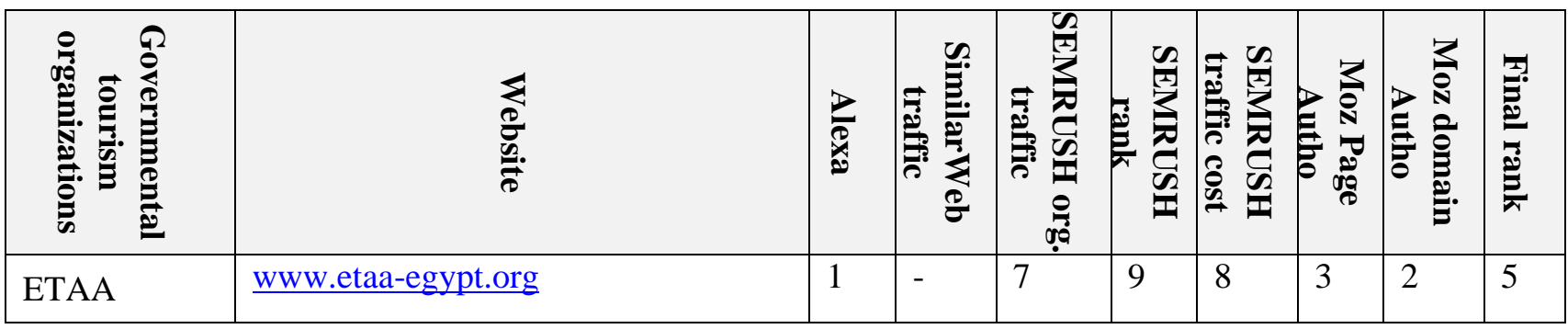

Accordingly, as shown in table 10, ETB website scored the first followed by MTA website.

Hence the rank for all the nine websites are:
1. www.egypt.travel
2. www.antiquities.gov.eg
3. http://trans.hajj.gov.eg/
4. www.misrtravel.net
5. www.etaa-egypt.org
6. www.hotac-eg.com
7. Egoth.com.eg
8. www.tda.gov.eg
9. www.etf.org.eg

\section{Conclusion}

Google Trends is important for content writers and service developers also. Hence, it can be accessed when several terms are most popular such as seasonal trends.

Keywords are also important to translate the searcher need and get the higher rank especially in trends. Governmental websites are informative but not as the private ones like www.trivago.com or www.booking. They need a lot of developing to match the market demand.

Alexa Rank measures how a website is running in according to all other sites, which makes as a good evaluation tool for benchmarking and competitive analysis. Alexa rank is calculated by using a proprietary methodology that takes a site estimated traffic and visitor engagement.

Search engine optimization tools such as Similarweb, SEMrush and MOZ can be used to help webmaster to get a high rank for his websites and make website appear first for different searchers. They measure how a website is running in according to all other sites, which makes as a good evaluation tools for benchmarking and competitive analysis. Such as Alexa rank which is calculated by using a proprietary methodology that takes a site estimated traffic and visitor engagement.

Hence, it is essential for the marketing managers with the helping of a business solution agent to:

- Enhance their website rank by selecting the most appropriate keywords by using SEO tools and apply it on their websites.

- Use the original and latest software and tools for the development of the website and updating the website with contents regularly.

- Check periodically the website rank through websites that provide web analytics. Ensure that the web pages have the most recent keywords which reflected in all the linking structures on the web pages like images, videos, and audios to get the value addition in the SEO methodology.

- Link the website with old popular websites which are online as Google and other search engines do indexation of old websites more frequently, which help in fast and easy crawling. 
- Perform website evaluation continuously to fix any troubles and get high rank.

\section{Study contribution}

The authors adopted traffic Estimate, Google trend, Alexa, SimilarWeb, SEMrush, and MOZ as SEO tools to compare and evaluate the Egyptian governmental websites for tourism. No such research was found in these criteria for Egypt. The authors tried to help websites managers to understand searchers needs by using suitable keywords in addition to be in the top rank accordingly getting the highest benefits from their websites.

\section{References}

Abou-Shouk, M. A., \& Khalifa, G. S. (2017). The influence of website quality dimensions on epurchasing behaviour and e-loyalty: a comparative study of Egyptian travel agents and hotels. Journal of Travel \& Tourism Marketing, 34(5), 608-623.

Abou-Shouk, M., \& Lim, W. M. (2010). Egyptian travel agents and e-commerce. Information and Communication Technologies in Tourism 2010, 357-368.

Al-Badi, A. H., Al Majeeni, A. O., Mayhew, P. J., \& Al-Rashdi, A. S. (2011). Improving website ranking through search engine optimization. Journal of Internet and e-business Studies, 2011, $1-11$.

Ankalkoti, P. (2017). Survey on Search Engine Optimization Tools \& Techniques. Imperial Journal of Interdisciplinary, 3, 40-43.

Chaffey, D., Ellis-Chadwick, F., Mayer, R., \& Johnston, K. (2009). Internet marketing: strategy, implementation and practice. Pearson Education.

Chaffey, D., Smith, P. R., \& Smith, P. R. (2013). eMarketing eXcellence: Planning and optimizing your digital marketing. Routledge.

Chen, C. Y., Shih, B. Y., Chen, Z. S., \& Chen, T. H. (2011). The exploration of internet marketing strategy by search engine optimization: A critical review and comparison. African Journal of Business Management, 5(12), 4644-4649.

Dou, W., Lim, K. H., Su, C., Zhou, N., \& Cui, N. (2010). Brand positioning strategy using search engine marketing. Mis Quarterly, 34(2), 261-279.

Egri, G., \& Bayrak, C. (2014). The role of search engine optimization on keeping the user on the site. Procedia Computer Science, 36, 335-342.

Furnell, S., \& Evans, M. P. (2007). Analysing Google rankings through search engine optimization data. Internet research, 17(1), 21-37.

García-Carretero, L., Codina, L., Díaz-Noci, J., \& Iglesias-García, M. (2016). Herramientas e indicadores SEO: Características y aplicación al análisis de cibermedios. El Profesional de la Información, 25(3), 497-504.

Gregurec, I., \& Grd, P. (2012). Search Engine Optimization (SEO): Website analysis of selected faculties in Croatia. In Central European Conference on Information and Intelligent Systems. Faculty of Organization and Informatics Varazdin.

Hefny, L. (2015). Evaluation of the websites Functionality of the Egyptian Intermediaries and defining barriers to online development. International Journal of Heritage, Tourism, and Hospitality, 9(2/2).

Hui, Z., Shigang, Q., Jinhua, L., \& Jianli, C. (2012),. Study on website search engine optimization. In 2012 international conference on computer science and service system. 930-933. 
Ji, S. W., Choi, Y. J., \& Ryu, M. H. (2016). The economic effects of domestic search engines on the development of the online advertising market. Telecommunications Policy, 40(10-11), 982-995.

Kaur, S., \& Kaur, K. Search Engine Optimization Techniques with Website Perspective. International Arab Journal of e-Technology, 4(3), 103-108.

Lepp, A., Gibson, H., \& Lane, C. (2011). Image and perceived risk: A study of Uganda and its official tourism website. Tourism management, 32(3), 675-684.

Marin, M., Gil-Costa, V., Inostrosa-Psijas, A., \& Bonacic, C. (2019). Hybrid capacity planning methodology for web search engines. Simulation Modelling Practice and Theory, 93, 148163.

Mataram, M. M. A., \& Mandiri, B. E. P. S. N. (2015). Influence of Classified Ad On Google Page Rank And Number Of Visitors. Publikasi Internasional, 1(1), 10-20.

Matosevic, G. (2014). Towards a metric for on-page search engine optimization. In Central European Conference on Information and Intelligent Systems, Faculty of Organization and Informatics Varazdin.

Patil Swati, P., Pawar, B. V., \& Patil Ajay, S. (2013). Search Engine Optimization: A Study. Research Journal of Computer and Information Technology Sciences, 1(1), 10-13.

Prathapan, M., Sajin Sahadevan, D., \& Zakkariya, K. A. (2018). Effectiveness of digital marketing: Tourism websites comparative analytics based on AIDA model. International Journal of Innovative Research \& Studies, 8(4), 262-273.

Rehman, K. U., \& Khan, M. N. A. (2013). The foremost guidelines for achieving higher ranking in search results through search engine optimization. International Journal of Advanced Science and Technology, 52(3), 101-110.

Reisinger, Y., Moufakkir, O., Hagag, W., Clark, L., \& Wheeler, C. (2015). A framework for understanding the website preferences of Egyptian online travel consumers. International Journal of Culture, Tourism and Hospitality Research, 9(1), 68-82.

Sánchez, D., Martínez-Sanahuja, L., \& Batet, M. (2018). Survey and evaluation of web search engine hit counts as research tools in computational linguistics. Information Systems, 73, 5060 .

Sirdeshmukh, D., Ahmad, N. B., Khan, M. S., \& Ashill, N. J. (2018). Drivers of user loyalty intention and commitment to a search engine: An exploratory study. Journal of Retailing and Consumer Services, 44, 71-81.

Vyas, C. (2019). Evaluating state tourism websites using Search Engine Optimization tools. Tourism Management, 73, 64-70.

Yalçın, N., \& Köse, U. (2010). What is search engine optimization: SEO? Procedia-Social and Behavioral Sciences, 9, 487-493.

Yew, G. C. K. (2019). Search engines and Internet defamation: Of publication and legal responsibility. Computer Law \& Security Review, 35(3), 330-343. 